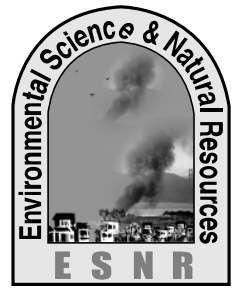

\title{
Status of Fisheries Resources and Water Quality of Tanguar Haor
}

\author{
S. A. Mamun ${ }^{1}$, S. Roy ${ }^{2}$, M. S. Rahaman ${ }^{1}$ Jahan $^{1}$ and M. S. Islam ${ }^{1}$ \\ ${ }^{1}$ Department of Environmental Science and Resource Management, \\ Mawlana Bhashani Science and Technology University, Santosh, Tangail-1902, Bangladesh \\ ${ }^{2}$ Department of Soil Science, University of Chittagong, Chittagong-4331, Bangladesh.
}

\begin{abstract}
The study was conducted to observe the status of fisheries resource of Tanguar haor, one of the large wetland in the north eastern part of Bangladesh. For this purpose the whole study was completed in two parts: interviewing with local people and analyzing the water quality. Indiscriminate harvesting of mother fishes, use of agrochemicals, sedimentation on haor basin and habitat destruction were found as major causes of fisheries resources degradation in the study area. Most of the water quality parameters were found good which were within the standard level set by Government of Bangladesh for fisheries. However, EC and TDS were found higher than the recommended level for fish production.
\end{abstract}

Key Words: Fisheries resource, Tanguar haor, Water quality, Wetland.

\section{Introduction}

Fresh water wetlands occupy a relatively small portion of the earth's surface but their importance to human beings is far greater than their areas (Regina and Nabi, 2003). Wetlands support many valuable aquatic flora and fauna including different species of fish such as Tor tor, Labeo angra Labeo nandina, Ompok pabda Nandus nandus, Channa marulius etc. (Sarma and Saikia, 2008). Wetlands cover more a significant area of Bangladesh. Some of these wetlands occur in the form of a Haor (Waliuzzaman et al., 2012). The haor basin has its commercial and ecological importance for fish production (Salauddin and Islam, 2011). Over the years, the population of natural fish species has declined considerably due to increased fishing pressure, and various anthropogenic activities leading to siltation, aquatic pollution, and loss of natural habitat for spawning and growth (Akhteruzzaman et al., 1998; Hussain and Mazid, 2001). On the other hand, the types and distribution of aquatic biota are directly influenced by the physico-chemical characteristics of the aquatic system (De, 2007). Now-a-days, the numbers of fish species are decreasing at an alarming rate as a result of aquatic pollution due to increasing industrialization, urbanization and development activities. Recently, the fish is considered as one of the most endangered aquatic resource in Bangladesh (IUCN, 1998). The fish production of $\mathrm{TH}$ is decreasing as a result of rampant harvesting of other fish, lack of river velocity for brood, use of agrochemicals, high population pressure, natural sedimentation on haor basin, destruction of habitats (Ahmed, 2008).

\section{Materials and Methods}

The study was carried out through analytical method and social surveys. The social survey was carried out to determine the past and present condition of fisheries resources, identify the causes of degradation of these resources and for better managements with the help of indigenous knowledge. The analytical study was carried out to determine the physical and chemical properties of water and to find out the suitability of this water for fish production by comparing the values with the standard levels of water quality parameters.

\section{Location of the study area}

The study was conducted in Tanguar haor which is located in Sunamganj district lying in north eastern part of Bangladesh.

\section{Data and sample collection}

Data was collected from local people who are directly and indirectly dependent on haor for their livelihood by questionnaire survey and laboratory analysis of samples. The water samples were collected from Majampur (S1), Lamagau (S2), Lamagaubeel (S3), Hoirakuna (S4), and Hoirakunain (S5) that lied between $25^{0} 06^{\prime \prime} .442 \mathrm{~N}, 91^{0} 03^{\prime \prime} .443 \mathrm{E}, 25^{0} 06 " .494 \mathrm{~N}$, $91^{0} 03^{\prime \prime} .451 \mathrm{E}, \quad 25^{\circ} 07^{\prime \prime} .003 \mathrm{~N}, \quad 91^{0} 03^{\prime \prime} .709 \mathrm{E}$, $25^{0} 07^{\prime \prime} .311 \mathrm{~N}, 91^{0} 03^{\prime \prime} .828 \mathrm{E}, 25^{\circ} 07^{\prime \prime} .351 \mathrm{~N}, 91^{\circ} 03^{\prime \prime} .848$ E respectively on May to June, 2012. From each sampling site water samples were collected in replicates. So, the total numbers of water samples collected from the area were fifteen. $250 \mathrm{ml}$ of water were collected separately in plastic bottles. Before sampling, the bottles were cleaned and washed with sampling water. Necessary information such as date of collection, location, source of water, time of collection was recorded.

\section{Method of analysis}

$\mathrm{pH}$. Electrical conductivity (EC), total dissolved solid (TDS) and dissolved oxygen (DO) were measurd by digital $\mathrm{pH}, \mathrm{EC}$, TDS and DO meters respectively. The temperature of the water was determined by digital thermometer. Data was processed and statistically analyzed by using SPSS 
statistical package (Evaluation version 14.0) and Microsoft Excel.

\section{Result and Discussion}

People's perceptions about the past and present status of fisheries resources, the causes behind the depletion of these resources are presented. The values of water quality parameters have also given to know whether the water is suitable for fish culture or not. To perform the survey work a total of 200 respondents of different categories were selected.
Profile of the participants of the study area Among the 200 respondents $78.5 \%$ were male and $21.5 \%$ respondents were female (Table 1). The respondents were also categorized according their age range, occupation and educational qualification. Table 1 show the general profile of the respondents where different occupational groups such as farmers, fishermen, housewives and management bodies were included.

Table 1. Profile of the respondent of the study area

\begin{tabular}{|l|l|c|c|}
\hline Indicators & Variable & Percent (\%) & No. of respondent (N) \\
\hline Sex & Male & 78.5 & 157 \\
& Female & 21.5 & 43 \\
\hline Age range in year & $18-30$ & 5.5 & 11 \\
& $31-42$ & 45.5 & 99 \\
& $42-54$ & 21.5 & 41 \\
& More than 54 & 24.5 & 49 \\
\hline Occupation & Farmer & 32.5 & 65 \\
& Fisherman & 27.5 & 55 \\
& Housewife & 20 & 40 \\
& Employee & 10 & 20 \\
& Management Bodies & 2.5 & 5 \\
& Specialist & 7.5 & 15 \\
\hline Educational qualification & Under primary & 53.5 & 107 \\
& Up to graduation level & 26.5 & 53 \\
& More than graduation & 20 & 40 \\
\hline
\end{tabular}

\section{General awareness about fisheries resources of $\mathrm{T} H$}

Most of the respondents (more than $90 \%$ ) were aware of the fisheries resources of $\mathrm{TH}$ from their continuous observation, from different advertisements and from different project implementing groups. But only $2 \%$ people were ignorant about the present status of fisheries and 5\% respondents had no idea about the previous (about 20 years ago) status of the fisheries resource of the $\mathrm{TH}$ (Table 2 ).

Table 2. Knowledge of respondents about the present and previous status of fisheries resource of TH

\begin{tabular}{|l|l|c|c|}
\hline Indicators & Variable & Percent (\%) & Total respondent (N) \\
\hline Present status of fisheries of TH & Known & 98 & 196 \\
\cline { 2 - 4 } & Unknown & 2 & 4 \\
\hline $\begin{array}{l}\text { Previous status of fisheries of TH } \\
\text { (about 20 years ago) }\end{array}$ & Known & 95 & 190 \\
\cline { 2 - 4 } & Unknown & 5 & 10 \\
\hline
\end{tabular}

\section{Status of Fish production of $\mathrm{TH}$}

Among the total respondents majority (95.5\%) said that the amount of fish production of TH is decreasing day by day while few $(3.5 \%)$ respondents said no change in production and very few $(1 \%)$ of them said fisheries resource is increasing day by day (Table 3 ). The estimated fish production of $\mathrm{TH}$ in 2008 was
6,500 MT (Ahmed, 2012). During NCS (National Conservation Strategy) study the estimated fish production of $\mathrm{T} \mathrm{H}$ was 5,500 MT (Ahmed, 2012) showing an increase in fish production. But in the survey the local people said the fisheries resource is decreasing day by day including specialist bodies.

Table 3. Respondent's opinion about Status of fish production of TH

\begin{tabular}{|l|c|c|}
\hline Variables & Percentage (\%) & Total No. of respondents (N) \\
\hline Decrease in production & 95.5 & 191 \\
\hline Increase in production Increasing & 1 & 2 \\
\hline No change in production & 3.5 & 7 \\
\hline
\end{tabular}




\section{Causes of fisheries resource declination}

To identify the causes of fisheries resource declination people were provided a sheet having a set of questions after a briefing about this. Respondent's opinion responsible for reduction of fisheries resource of $\mathrm{TH}$ are given in Table 4. Indiscriminate harvest of mother fishes was found as a major cause of fish declination. In addition, corruption, illegal fishing, use of agrochemicals and habitat destruction were also found as reasons for the reduction of fish species in the study area. Some of the respondents stated water pollution as a cause of fisheries resource declination.

Table 4. Causes of fisheries resource declination of $\mathrm{TH}$

\begin{tabular}{|c|c|c|}
\hline Main causes of fisheries resource declination & Percent $(\%)$ & Total respondent $(\mathrm{N})$ \\
\hline Over exploitation of fishes & 21.5 & 43 \\
\hline Mismanagement & 4 & 8 \\
\hline Illegal fishing & 11 & 22 \\
\hline Corruption & 17.5 & 35 \\
\hline Structural development & 6 & 12 \\
\hline Habitat destruction & 9.5 & 19 \\
\hline Use of agrochemicals & 9 & 18 \\
\hline Population pressures & 7 & 14 \\
\hline Changed fishing pattern & 1 & 2 \\
\hline Sedimentation in hoar & 6.5 & 13 \\
\hline Water quality degradation & 3.5 & 7 \\
\hline Others causes & 3.5 & 7 \\
\hline
\end{tabular}

According to Ahmed (2008) illegal fishing, natural sedimentation on haor basin, indiscriminate reeds and bushes collection from the haor, habitation loss, catching mother fishes are mostly responsible for the fish degradation in TH. He also mentioned that Ujja fishing, one type of festival, is another major cause for declining the quantitative amount of the fisheries resource (Ahmed, 2008). Due to population explosion during last few decades the pressure of Ujja fishing has increased which results in depletion of mother fishes.

\section{Water quality of $\mathrm{TH}$}

To find out the suitability of water of $\mathrm{TH}$ for fisheries some basic water quality parameters were studied.
The mean values of $\mathrm{pH}, \mathrm{EC}$, TDS, DO and temperature of water collected from five different location of TH are given in Table 5. Water color of most of the sampling sites of TH was light green. In some places water was deep green in color. No bad odor was found in water of the study area. The average $\mathrm{pH}$ of the water samples ranged from 6.9 to 7.6. The highest value was found at Majampur and lowest value was found at Hoirakuna. The standard value of $\mathrm{pH}$ for fisheries lies between 6.5 to 8.5 (ECR, 1997). It is obvious from the value of $\mathrm{pH}$ that the water is suitable for fish production and other aquatic organisms.

Table 5. Status of water quality at different points of the study area.

\begin{tabular}{|l|c|c|c|c|c|c|}
\hline Sampling sites & Color & $\mathrm{pH}$ & DO $(\mathrm{mg} / \mathrm{l})$ & TDS $(\mathrm{mg} / \mathrm{l})$ & EC $(\mu \mathrm{S} / \mathrm{cm})$ & Temperature $\left({ }^{\circ} \mathrm{C}\right)$ \\
\hline S1 & Light green & 7.4 & 5.5 & 731 & 1070 & 28 \\
\hline S2 & Light green & 7.2 & 5 & 670 & 1044 & 28 \\
\hline S3 & Light green & 7.5 & 5.2 & 1036 & 1658 & 28 \\
\hline S4 & Deep green & 7.6 & 4.5 & 805 & 1250 & 28.1 \\
\hline S5 & Light green & 6.9 & 4.9 & 988 & 1450 & 27.8 \\
\hline Mean & & 7.32 & 5.02 & 846 & 1294 & 28 \\
\hline
\end{tabular}

Like $\mathrm{pH}$, the lowest mean value $(4.5 \mathrm{mg} / \mathrm{l})$ of $\mathrm{DO}$ at Hoirakuna and highest value $(5.5 \mathrm{mg} / \mathrm{l})$ was found at Majampur. The mean value of DO of all the sampling sites was found $5.02 \mathrm{mg} / \mathrm{l}$. According to ECR (1997) surface water having DO value 5 or more is suitable for fisheries. It is revealed from the study that TDS values of different sampling stations were ranging from 670 to $1036 \mathrm{mg} / \mathrm{l}$. The highest TDS value was observed at the $\mathrm{S} 3$ which is the mouth of a channel and the lowest was found at the S2. The mean value of all the sampling sites was $846 \mathrm{mg} / \mathrm{l}$. All the values were found higher than the standard value of $500 \mathrm{mg} / \mathrm{l}$ for fisheries. The higher TDS value of water may be due to the high contents of dissolved ions in water that flows from upstream and nearby agricultural land. The average EC values measured at different sampling stations ranged from 1044 to $1658 \mu \mathrm{S} / \mathrm{cm}$ with the mean value of $1294.4 \mu \mathrm{S} / \mathrm{cm}$ of all the 
sampling sites. The highest EC value was found at S3. EC values ranging from $800-1000 \mu \mathrm{S} / \mathrm{cm}$ are standard for fisheries. All the values were found above the standard level which may be due to presence of high salt running off from nearby agricultural land. A little difference was found in temperature among all the sampling stations of $\mathrm{TH}$ ranged from 27.8 to 28.1 It is observed that the average temperature is 27.98 where minimum at S5 and maximum at the point $\mathrm{S} 4$.

\section{Conclusion}

The water quality of the study area was relatively good except the TDS and EC. All the values represent good quality water for aquatic organisms. From survey it is obvious that the main causes of fisheries declination are over exploitation of resources due to rapid population growth and illegal fishing.

\section{References}

Ahmed, M. 2008. Ujja Fishing. Protection and Management Report. Fish migration and management in Tanguar Haor. TARA (Technical Assistance for Rural Advancement), IUCN, SDC (Swiss Agency for Development and Cooperation). pp. 1-30.

Ahmed, M. 2012. Community led framework for estimation of sustainable exploitation level of fish and reeds in Tanguar Haor. Community Based Sustainable Management of Tanguar Haor Project-II, IUCN, SDC (Swiss Agency for Development and Cooperation). pp. 1-30.

Akhteruzzaman, M.; Kohinoor, A. H. M.; Islam, M. S. and Modak, P. C. 1998. Observations on the induced breeding of indigenous small fish. Bhagna (CirrhinusrebaHam.) in Bangladesh, Progressive Agriculture, 9(12): 281-284.

De, A. K. 2007. Environmental Chemistry. $6^{\text {th }}$ edition. New Age Int. (P) Ltd. New Delhi. pp 169-170.
ECR. 1997. The Environment Conservation Rules. Government of the People's Republic of Bangladesh. Ministry of Environment and Forest. pp. 205-207.

Hussain, M. G. and Mazid, M. A. 2001. Genetic improvement and conservation of carp species in Bangladesh, Bangladesh Fisheries Research Institute and International Center for Living Aquatic Resources Management, Bangladesh, pp. 74.

IUCN (Bangladesh). 1998. List of threatened animals of Bangladesh. Paper presented in the special workshop on Bangladesh Red Book of Threatened Animals, 22 February 1998, Dhaka, pp. 13.

Regina, B. and Nabi, B. 2003. Physico-chemical spectrum of the Bhavani river water collected from the Kalingaryan dam, Tamilnadu. Indian J. Environ. and Ecoplan., 7(3): 633-636.

Salauddin M. and Islam, A.K.M. S. 2011. Identification of land cover changes of the haor area of Bangladesh using Modis Images, 3rd International Conference on Water \& Flood Management (ICWFM2011), pp. 1-7.

Sarma, S. K. and Saikia, M. 2008. Utilization of wetland resources by the rural people of Nagaon district Assam, Indian Journal of Traditional Knowledge., 9(1):145-151.

Waliuzzaman, M.; Neyamat, H.; Islam, S.; Munjurul, S. M.; Khan, H. and Nishat, A. 2012. Livelihoods, Security and Conflict -Tanguar Haor, Bangladesh, Resource Rights, Sustainable Livelihoods. Environmental Security and Conflict Mitigation in South Asia, pp. 21-45. 